\title{
Histological analysis of elastic cartilages treated with alkaline solution
}

[Análise histológica de cartilagens elásticas tratadas com solução alcalina]

\author{
K.D. Ferreira ${ }^{1}$, L.D. Cardoso $^{2}$, L.P. Oliveira ${ }^{1}$, V.S. Franzo $o^{3}$,
}

A. Pancotti ${ }^{4}$, M.P. Miguel ${ }^{5}$, L.A.F. Silva ${ }^{6}$, V.A.S. Vulcani ${ }^{6,7^{*}}$

\author{
${ }^{1}$ Aluna de pós-graduação - Escola de Veterinária e Zootecnia - Universidade Federal de Goiás - Goiânia, GO \\ ${ }^{2}$ Aluna de pós-graduação - Universidade Federal de Jataí - Jataí, GO \\ ${ }^{3}$ Universidade Federal do Mato Grosso - Cuiabá, MT \\ ${ }^{4}$ Universidade Federal de Jataí - Jataí, GO \\ ${ }^{5}$ Instituto de Patologia Tropical e Saúde Pública - Universidade Federal de Goiás, Goiânia, GO \\ ${ }^{6}$ Escola de Veterinária e Zootecnia - Universidade Federal de Goiás - Goiânia, GO \\ ${ }^{7}$ Unidade Acadêmica Especial de Ciências Agrárias - Universidade Federal de Jataí - Jataí, GO
}

\begin{abstract}
The elastic cartilage is composed by chondroblasts and chondrocytes, extracellular matrix and surrounded by perichondrium. It has a low regeneration capacity and is a challenge in surgical repair. One of obstacles in engineering a structurally sound and long-lasting tissue is selecting the most appropriate scaffold material. One of the techniques for obtaining biomaterials from animal tissues is the decellularization that decreases antigenicity. In this work, alkaline solution was used in bovine ear elastic cartilages to evaluate the decellularization and the architecture of the extracellular matrix. The cartilages were treated in alkaline solution (pH13) for 72 hours and lyophilized to be compared with untreated cartilages by histological analysis (hematoxylin-eosin, Masson's trichrome and Verhoeff slides). Areas of interest for cell counting and elastic fiber quantification were delineated, and the distribution of collagen and elastic fibers and the presence of non-fibrous proteins were observed. The results demonstrated that the alkaline solution caused $90 \%$ decellularization in the middle and $13 \%$ in the peripheral region, and maintenance of the histological characteristics of the collagen and elastic fibers and non-fibrous protein removal. It was concluded that the alkaline solution was efficient in the decellularization and removal of non-fibrous proteins from the elastic cartilages of the bovine ear.
\end{abstract}

Keywords: cartilage, tissue engineering, surgery, biocompatibility, antigen

\section{RESUMO}

A cartilagem elástica é composta por condroblastos e condrócitos, matriz extracelular e envolta por pericôndrio. Possui uma baixa capacidade de regeneração e é um desafio em reparos cirúrgicos. Um dos obstáculos na engenharia de tecido estruturalmente sólido e de longa duração é a seleção do material de arcabouço mais adequado. Uma das técnicas para obtenção de biomateriais oriundos de tecidos animais é a descelularização, que diminui a antigenicidade. Neste trabalho, foi utilizada solução alcalina em cartilagem elástica auricular bovina para avaliar a descelularização e a arquitetura da matriz. extracelular. As cartilagens foram tratadas em solução alcalina (pH13) durante 72 horas e liofilizadas, $e$ comparadas com cartilagens não tratadas por análise histológica (hematoxilina-eosina, tricrômio de Masson e Verhoeff). Foram determinadas as áreas de interesse para contagem celular e quantificação de fibras elásticas, observada a distribuição de colágeno e fibras elásticas e a presença de proteínas não fibrosas. Os resultados demonstraram que a solução alcalina causou $90 \%$ de descelularização na região central e $13 \%$ na região periférica, manutenção das características histológicas do colágeno e fibras elásticas e remoção das proteínas não fibrosas. Concluiu-se que a solução alcalina foi eficiente na descelularização e retirada de proteínas não fibrosas de cartilagens elásticas da orelha de bovinos.

Palavras-chave: cartilagem, engenharia de tecidos, cirurgia, biocompatibilidade, antígeno

Recebido em 22 de maio de 2019

Aceito em 24 de outubro de 2019

*Autor para correspondência (corresponding author)

E-mail: aloisiosv@hotmail.com 


\section{INTRODUCTION}

Elastic cartilage is a yellowish flexible cartilage occurring chiefly in the external ear, auditory tube, and some cartilages of the larynx and epiglottis. It is surrounded by perichondrium and characterized by the presence of chondrocytes immersed in an extracellular matrix (ECM) rich in elastic and type II collagen fibers and proteoglycans (Mills, 2012). The threedimensional organization of ECM molecules confers elasticity, flexibility and resistance to tensile and compression to the elastic cartilage (Gaut and Sugaya, 2015; Mescher, 2015). Elastic cartilage has a limited capacity to regenerate, and plastic and reconstructive surgical treatment is still challenging. Therefore, an effective treatment for the reconstruction of tissues and organs composed of elastic cartilage is still needed (García-Martínez et al., 2017). Moreover, in human and veterinary medicine there is constant need for resistant biomaterials to be used as substitutes or helpers in several extensive tissue loss. In such circumstances, the biomaterial can be found not only as a bioimplant with an anatomical impact but also as a substitute for a regenerative process (Vega-Ruiz et al., 2017).

Tissue engineering offers the possibility to generate different kinds of tissues or organs by using cells, biomaterials and growth factors (Silva et al., 2013). Several biomaterials have been used in cartilage tissue engineering, and it is currently accepted that these biomaterials should be biodegradable, biocompatible, nontoxic and mechanically stable. In addition, these biomaterials should allow chondrocytes to proliferate, migrate, differentiate and finally become integrated in vivo (García-Martínez et $a l .$, 2017; Nayyer et al., 2012). In cartilage tissue engineering, scaffolds can provide threedimensional structure for cartilage cells and mediate cell-cell signaling and interaction. For this, the physical and biochemical properties are crucial for the scaffolds on the entire tissue repair process (Cao et al., 2014).

of the ears, the material was taken to the laboratory to continue processing.

The cartilage was dissected, cleaned, and submerged in saline solution for an hour. Ten pieces of cartilage were fixed in a $10 \%$ formalin solution - Control Group (CG) and the remaining
One of obstacles in engineering a structurally sound and long-lasting cartilage is selecting the most appropriate scaffold material, which should provide a proper environment for cell repopulation and function, however, an optimal scaffold still remains elusive. For this unmet need, decellularization that involves extracting cellular material from tissues to generate a structurally intact extracellular matrix (ECM) has been performed to generate scaffolds for use in tissue engineering. The ECM may serve as an ideal natural scaffold material because it retains functional proteins of the original tissue that stimulates cell growth (Graham et al., 2016).

Various methods, including physical, chemical, and biological techniques are used throughout the process of decellularization. Using chemical methods facilitates decellularization and includes chemical agents, acid and bases, detergents, alcohols, hypotonic and hypertonic solutions (Zahmati et al., 2017). In Brazil, researchers developed an alkaline solution ( $\mathrm{pH} 13)$, used it in animal tissues and reported the capacity of decellularization with maintenance of the architecture of the extracellular matrix (Goissis et al., 2000; Horn et al., 2009). However, although the solution has been used in elastic cartilage, there are no quantitative histological descriptions of the decellularization capacity and of characteristics of the extracellular matrix, after treatment for this type of tissue.

Thus, this work aimed to treat elastic cartilages of the bovine ear in alkaline solution for 72 hours and to evaluate the histological alterations, mainly the capacity of decellularization and modifications in the extracellular matrix.

\section{MATERIALS AND METHODS}

The study was conducted after approval by the Ethics Committee on the Use of Animals. Twenty elastic cartilage samples obtained from the external ear of adult bovine slaughtered under federal inspection were used. After harvest

were packed separately in plastic bags, frozen at $15^{\circ} \mathrm{C}$, and sent to the Laboratory of Biochemistry and Biomaterials at the Chemistry Institute of the São Paulo University (USP) - São Carlos, to be subjected to alkaline treatment - Alkaline Group (AG). In the laboratory, the material was defrosted and immersed in a $0.9 \%$ sodium 
chloride solution for four hours, and the solution was changed every hour. Subsequently, the cartilage was treated in an alkaline solution containing salts (chlorides and sulfates) of alkaline $(\mathrm{K}+$ and $\mathrm{Na}+)$ and alkaline earth metals $(\mathrm{Ca}+2)$ as described earlier (HORN et al., 2009). After alkaline treatment, the material was refrigerated and subsequently frozen at $-15^{\circ} \mathrm{C}$. It was then freeze-dried, lyophilized, and packed in plastic bags.

AG cartilages were fixed in a $10 \%$ formalin solution and the $\mathrm{AG}$ and $\mathrm{CG}$ samples were subjected to dehydration by immersing in solutions containing increasing concentrations of alcohol (70 to 100\%) for four hours. On completion of this step, diaphanization, inclusion, microtomy and staining by hematoxylin and eosin (HE), Masson's Trichrome and Verhoeff (Behmer and Tolosa, 2003). The CG samples were standard for cell counts, amount of elastic fibers and characteristics of the extracellular matrix amorphous substance.

HE slides were analyzed in light microscopy (400x magnification) for chondrocyte count. Two distinct regions of the sample were defined for the selection of the fields to be analyzed: middle region of the cartilage and the peripheral region, close to perichondrium. For count, intact cells with nucleus were considered. Six regions of interest $\left(\mathrm{ROI}=399.22 \times 299.22 \mu \mathrm{m}^{2}\right)$ of each slide were captured. Because the peripheral region is present on both sides of the cartilage, three random fields near the lower perichondrium and three random fields near the upper perichondrium were collected. Then, the cell densities of the middle region (CDmr) and peripheral region $(\mathrm{CDpr})$ were calculated by dividing total number of chondrocytes counted in each region by total area analyzed in the sample, according to equations 1 and 2 (XU et al., 2017).

$$
\begin{gathered}
\text { Equation } 1-C D m r=\frac{\text { Total chondrocytes in the middle region }}{\text { Total area of the middle region }} \\
\text { Equation } 2-C D p r=\frac{\text { Total chondrocytes in the peripheral region }}{\text { Total area of the peripheral region }}
\end{gathered}
$$

The elastic fibers were checked in Verhoeff slides for distribution around the chondrocytes, network arrangement in the extracellular matrix and their continuity and fragmentation. For fiber quantification six random fields of mean region $\left(\mathrm{ROI}=399.22 \times 299.22 \mu \mathrm{m}^{2}\right)$ of each slide were captured, as described in the cell counting method. The images were treated in the ImageJ software for increased sharpness of elastic fibers. Total area of fibers and elastic fibers density (EFD) were calculated by mean of the captured images area according to Equation 3:

$$
\text { Equation } 3-E F D=\frac{\text { Total elastic fibers }}{\text { Total area of the middle region }}
$$

For Masson's Trichrome, CG and AG slides were evaluated for the presence or absence of fibrous proteins of extracellular matrix and tinctorial affinity in the peripheral and central regions. The slides were observed under $100 \mathrm{X}$ magnification to verify differences in colorations among the regions and then under $400 \mathrm{X}$ to verify the regions near the cells and the matrix between them. The classification was qualitative, verifying the intensity of staining, in comparison to the control group. For statistical analysis, total cell counts and total area of elastic fibers values were tested by Shapiro-Wilk normality test. The treatments were compared by Holm-Sidak test, with a significance level of $5 \%$.

\section{RESULTS}

The total area of the regions of interest (ROI) was $716,727.65 \mu \mathrm{m}^{2} \quad\left(0.716 \mathrm{~mm}^{2}\right)$, resulting from captured images in $40 \mathrm{X}$ objective in six fields [(399.22 x 299.22) x 6]. The histological images of elastic cartilage in peripheral and middle regions are shown in Figure 1. The total counts and cell densities in the peripheral and middle regions are compiled in Figures 2 and 3. In the peripheral region cell count CG presented mean of $50.91 \pm 5.24$ and $A G$ of $43.83 b \pm 6.52$. For middle region $\mathrm{CG}$ presented mean of $38.41 \pm 5.58$ and $A G$ of $0.33 \pm 1.65$. There was significant difference for both regions $(\mathrm{P}<0.05)$. The mean 
of CDpr was $843.63 \mathrm{a} \pm 17.00$ for $\mathrm{CG}$ and $675,60 \mathrm{~b} \pm 27.04$ for AG. The mean of CDmr was $644.41 \pm 14.93$ for $\mathrm{CG}$ and $4.23 \pm 1.90$ for $\mathrm{AG}$. $(\mathrm{P}<0.05)$. There was significant difference for both regions $(\mathrm{P}<0.05)$. Considering $\mathrm{CG}$ as a parameter for the total number of cells and cell density for AG, there was a $13 \%$ reduction of cells in the peripheral region and $99.1 \%$ in the middle region and reduction of cell density by $20 \%$ in the peripheral region and $99.3 \%$ in the middle region.
It was simple to visualize elastic fibers in GA slides because the alkaline treatment removed the non-fibrous proteins of extracellular matrix. The fibers had good tinctorial affinity, resembling the coloration of CG (Figure 4). In $\mathrm{CG}$ and $\mathrm{AG}$ elastic fibers were distributed as a mesh around chondrocytes and emitted finer filaments in the extracellular matrix according to the natural characteristics of the elastic cartilage (Daamen et al., 2007).

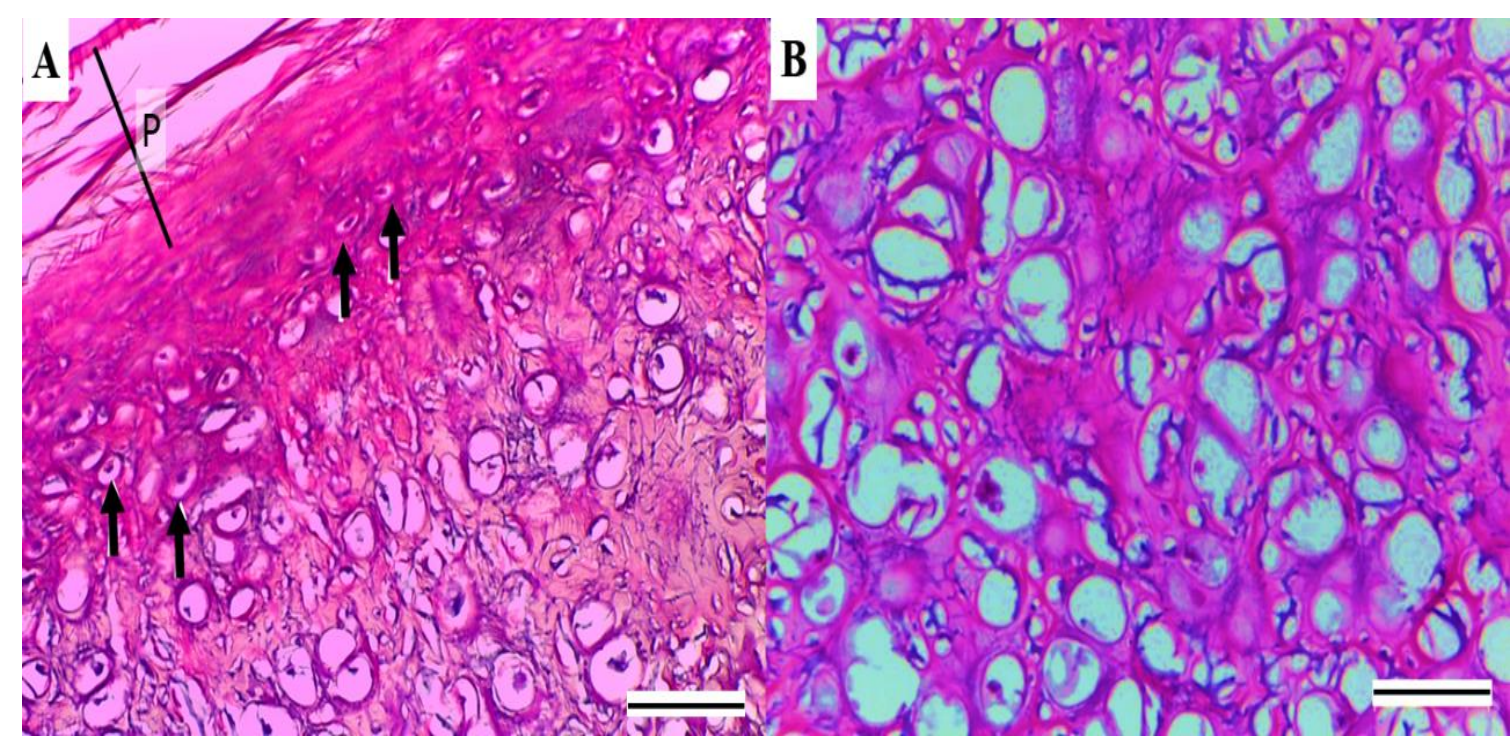

Figure 1. Histological images of bovine elastic cartilage treated in alkaline solution. In A, peripheral region with intact cells (arrows) and perichondrium (P). In B, the middle region without cells. H.E. 400x. Bar $-50 \mu \mathrm{m}$.
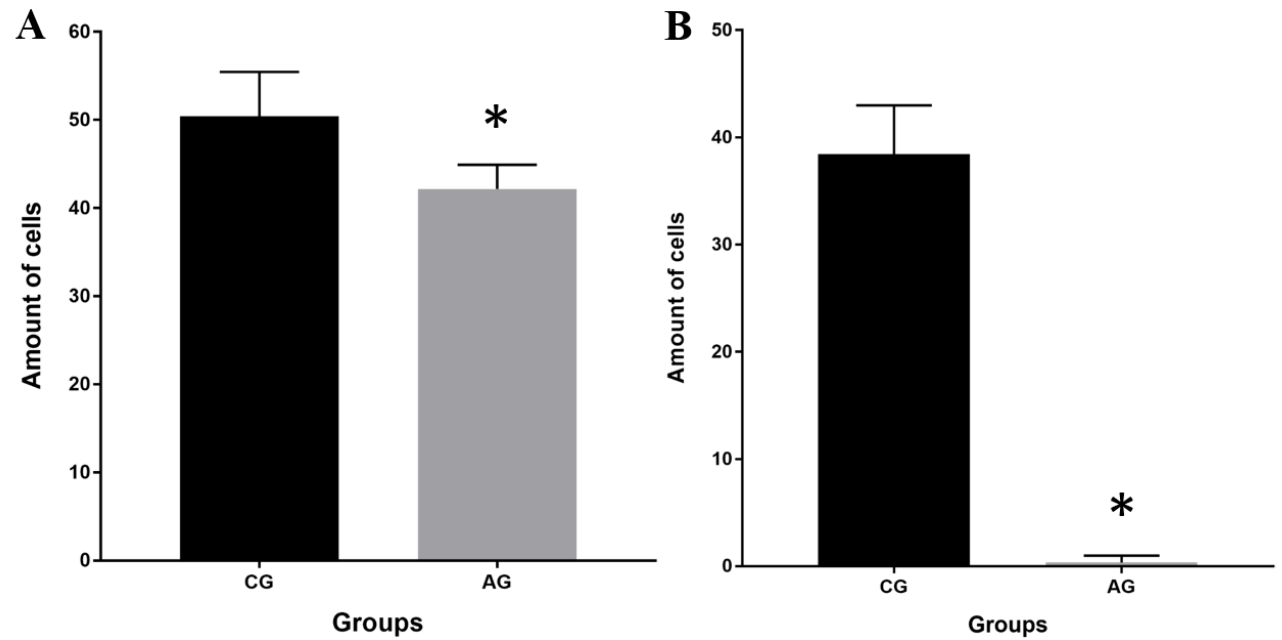

Figure 2. Number of cells in peripheral (A) and middle (B) regions for CG and AG. Asterisk - significant difference $(\mathrm{P}<0.05)$. 

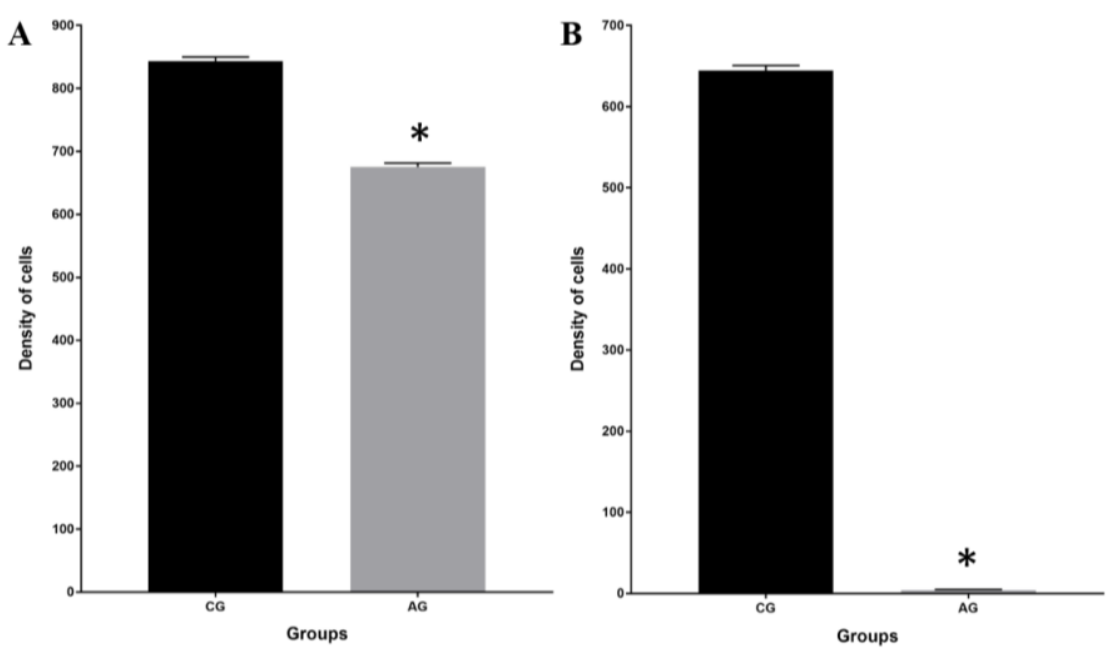

Figure 3. Cell densities in peripheral (A) and middle (B) regions for CG and AG. Asterisk - significant difference $(\mathrm{P}<0.05)$

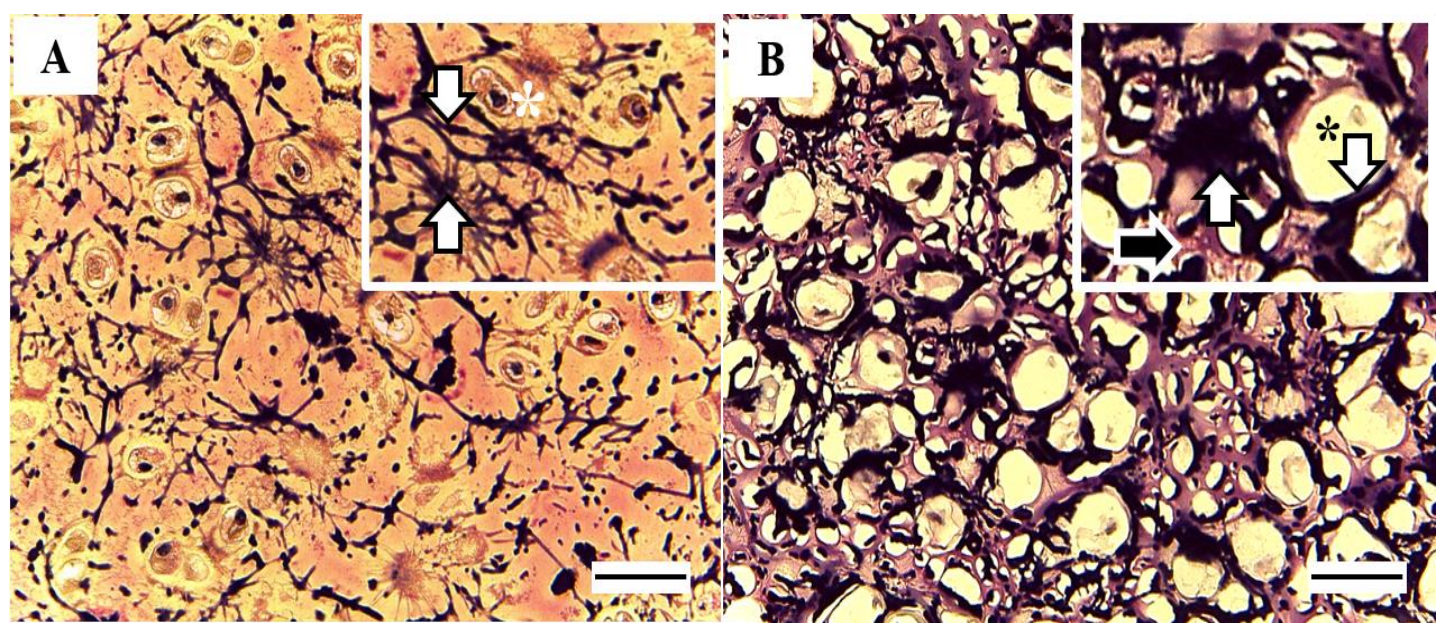

Figure 4. Histological images of bovine elastic cartilage. A - Untreated cartilage (CG). In highlighted square, chondrocyte (white asterisk) with elastic fibers around (down arrow) and elastic fibers filaments between cells (Up arrow). B - Treated cartilage (AG). In highlighted square gap (black asterisk) with elastic fibers around (down arrow) and elastic fibers filaments between cells (Up arrow) and collagen fibers (black arrow). HE and Verhoeff, 400X. Bar $-50 \mu \mathrm{m}$.

Although the visualization of the fibers was easier in $A G$, the quantification of elastic fibers showed that there is no significant difference for total amount of fibers per area and in the density of fibers by the region of interest in relation to the CG (Table 1). The absence of non-fibrous proteins is verified in $\mathrm{AG} \mathrm{HE}$ and Verhoeff stained slides (Figure 4B) with exposed collagen fibers. This is also visible in AG Masson's Trichrome stained slides (Figure 5).

Table 1. Area (mean and standard deviation) and density of elastic fibers in the regions of interest

\begin{tabular}{ccc}
\hline Group & Total area & Density \\
CG & $95,506.39^{\mathrm{a}} \pm 620.03$ & 0.79 \\
AG & $85,652.55^{\mathrm{a}} \pm 1,776.91$ & 0.71 \\
\hline
\end{tabular}

Means with the same letter in the same line do not differ significantly. 


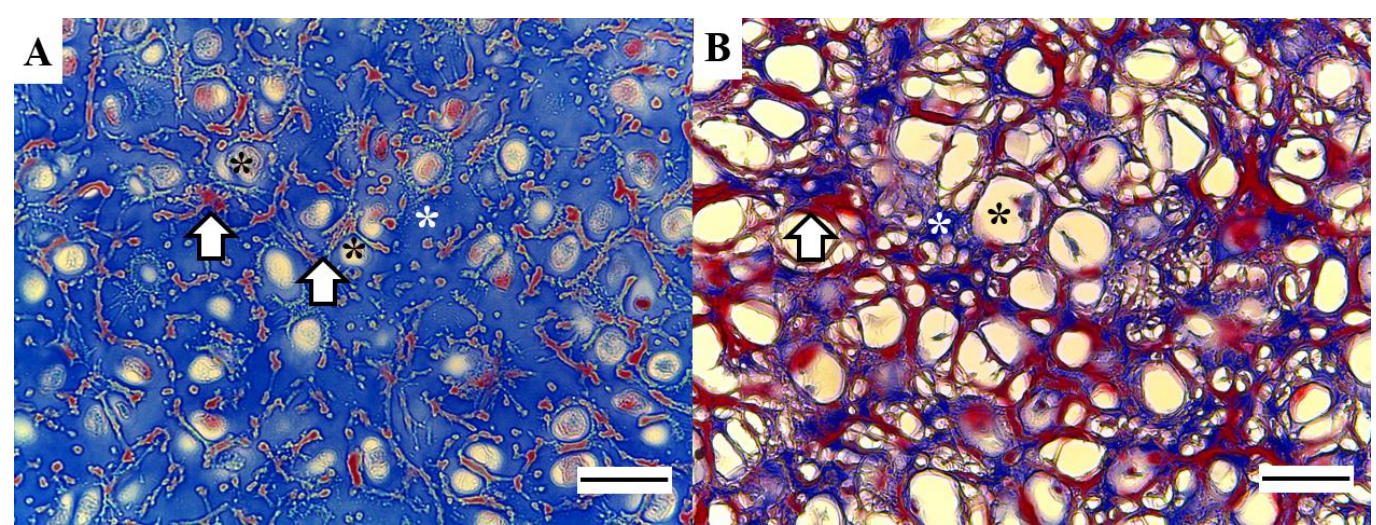

Figure 5. Histological image of bovine elastic cartilage. A - Untreated cartilage (CG), chondrocyte (black asterisk), extracellular matrix (white asterisk) with elastic fibers around and elastic fibers filaments between cells (arrows). B - Treated cartilage (AG), gap (black asterisk), elastic fibers (arrow) and collagen fibers (white asterisk). Masson's Trichrome, 400X. Bar $-50 \mu \mathrm{m}$.

\section{DISCUSSION}

The knowledge of the structural characteristics of biomaterials is crucial in the design of new biomasses before their use in the clinical setting. Ideally, an implant should provide mechanical properties matching those of the tissue to be substituted and promote cell proliferation (Badylak and Gilbert, 2008). Among animal tissues selected for biomedical applications, bovine elastic cartilage has some particularly favorable features. Two inseparable biologic surfaces are detectable in the bovine elastic cartilage: the fibrous dense connective tissue (perichondrium) and the cartilaginous layer. The perichondrium is composed mostly of fibroblasts and collagen fibers, while the cartilage is composed of chondroblasts, chondrocytes, collagen and elastic fibers and non-fibrous proteins (Liu et al., 2017; Liu et al., 2016). The ability to preserve the extracellular matrix structure after decellularization plays a pivotal role to maintain a suitable microenvironment for facilitating cell growth (Brown and Badylak, 2014). Therefore, the use of decellularized bovine elastic cartilage appears to be particularly suitable for the treatment of multiple pathological conditions.

Here we present unprecedented results of bovine elastic cartilage decellularization in alkaline solution developed by Brazilian researchers. This protocol is efficient for decellularizing animal tissues and maintaining the structure of extracellular matrix fibrous proteins such as collagen and elastin (Horn et al., 2009). For this study, the histological structure of decellularized bovine elastic cartilage was investigated in comparison with a non-treated one, that is a typical practice in the study of biological tissue in order to define its potential application in the biomedical field (Bielli et al., 2018; Cebotari et al., 2010). The results of alkaline solution decellularization demonstrated efficiency of $90 \%$ in the middle region and $13 \%$ in the peripheral region of elastic cartilage. Tissue decellularization decreases antigenicity because it reduces the amount of cell membrane antigens, such as the oligosaccharide galactose- $\alpha$ (1.3)galactose ( $\alpha$-gal) epitope "Gal epitope" and the histocompatibility complex (MHC) molecule cells. The Gal is found in high density as a cell surface molecule in most species with exceptions of humans and OldWorld monkeys and promotes hyperacute rejection. The MHC molecules represent the most critical mediator of chronic rejection. The MHC I molecule, equivalent to human leukocyte antigen (HLA) I in non-human species, is located in the cell membrane of all nucleated cells. The MHC II molecule is found on specialized antigen presenting cells of the immune system (Wong and Griffiths, 2014).

The alkaline solution utilized for AG did not modify the histologic characteristics of collagen and elastic fibers, similar to the observed by BET et al. (2001). Bielli et al. (2018) used hypertonic solution followed by alkaline and neutralizing solutions, bacteriostatic solutions and radiation in bovine pericardium. For these authors, the analysis of histochemical staining by Masson's Trichrome and Verhoeff-Van Gieson confirmed 
the maintenance of the morphological appearance of both collagen and elastic fibers, like in this work. In addition, previous work demonstrated by thermal analysis and SDS polyacrylamide gel electrophoresis the maintenance of collagen structure in bovine pericardium after treatment in alkaline solution for 72 hours (BET et al., 2001). Regarding the elastic fibers, it was expected that alkaline treatment at $\mathrm{pH} 13$ would not alter the distribution characteristics, like in the CG slides. While most proteins are easily denatured (and solubilized) under heat and extreme conditions of $\mathrm{pH}$, elastin survives because of its unique chemical composition and highly cross-linked nature. Crosslinking results in mature elastin which is insoluble and extremely stable (Mecham, 2008).

The preservation of morphology, collagen and elastic fiber alignment and thermal stability of ECM structure, it is possible that the xenogeneic scaffold be identify as self. In turn, foreign body response and subsequent fibrous encapsulation of the graft may be avoided (Wong et al., 2016).

In addition to decellularization, the alkaline solution resulted in the removal of non-fibrous proteins from the extracellular matrix. There is still a large debate regarding the importance of spatial relationships between ECM components and complete ECM composition to determine the ultimate utility of a biomaterial (AAMODT and Grainger, 2016). The maintenance of these nonfibrous proteins may be important for questions related to structure and mechanical resistance but may act as antigens and provoke reactions at the implant receptor (Badylak et al., 2011). In this work, the information obtained by the histological analysis corroborates previous works and demonstrates that the technique is promising for obtaining cartilaginous biomaterials to be applied in tissue engineering.

\section{CONCLUSIONS}

It was concluded that the alkaline solution used for 72 hours provided almost complete decellularization of bovine ear elastic cartilage, removal of non-fibrous proteins and preservation of extracellular matrix fibrous proteins. It is suggested that new studies be carried out for the physical-chemical characterization and the biocompatibility of the treated material.

\section{ACKNOWLEDGEMENTS}

This study was financed in part by the Coordenação de Aperfeiçoamento de Pessoal de Nível Superior - Brasil (CAPES) - Finance Code 001 .

\section{REFERENCES}

AAMODT, J.M.; GRAINGER, D.W. Extracellular matrix-based biomaterial scaffolds and the host response. Biomaterials, v.86, p.6882, 2016.

BADYLAK, S.F.; GILBERT, T.W. Immune response to biologic scaffold materials. Semin: Immunol., v.20, p.109-116, 2008.

BADYLAK, S.F.; TAYLOR, D.; UYGUN, K. Whole-Organ Tissue Engineering: Decellularization and Recellularization of ThreeDimensional Matrix Scaffolds. Ann. Rev. Biomed. Eng., v.13, p.27-53, 2011.

BEHMER, O.A.; TOLOSA, E.M. C. Manual de técnicas para histologia normal e patológica. Barueri: Manole, 2003. 341p.

BET, M.R.; GOISSIS, G.; LACERDA, C.A. Characterization of polyanionic collagen prepared by selective hydrolysis of asparagine and glutamine carboxyamide side chains. Biomacromolecules, v.2, p.1074-1079, 2001.

BIELLI, A.; BERNARDINI, R.; VARVARAS, D. et al. Characterization of a new decellularized bovine pericardial biological mesh: Structural and mechanical properties. J. Mech. Behav. Biomed. Mater., v.78, p.420-426, 2017.

BROWN, B.N.; BADYLAK, S.F. Extracellular matrix as an inductive scaffold for functional tissue reconstruction. Transl. Res., v.163, p.268285,2014

CAO, Z.; DOU, C.; DONG, S. Scaffolding biomaterials for cartilage regeneration. $J$. Nanomater., v.2014, 8p., 2014.

CEBOTARI, S.; TUDORACHE, I.; JAEKEL, T. et al. Detergent decellularization of heart valves for tissue engineering: toxicological effects of residual detergents on human endothelial cells. Artif. Organs., v.34, p.206-210, 2010.

DAAMEN, W.F.; VEERKAMP, J.H.; VAN HEST, J.C.M. et al. Elastin as a biomaterial for tissue engineering. Biomaterials, v.28, p.43784398, 2007. 
GARCIA-MARTINEZ， L.; CAMPOS， F.; GODOY-GUZMAN, C. et al. Encapsulation of human elastic cartilage-derived chondrocytes in nanostructureed fibrin-agarose hydrogels. Histochem. Cell Biol., v.147, p.83-95, 2017.

GAUT, C.; SUGAYA, K. Critical review on the physical and mechanical factors involved in tissue engineering of cartilage. Regenerative Med., v.10, p.665-679, 2015.

GOISSIS, G.; SUZIGAN, S.; PARREIRA, R.P. et al. Preparation and characterization of collagen-elastin matrices from blood vessels intended as small diameter vascular grafts. Artif. Organs., v.24, p.217-223, 2000.

GRAHMAN, M.E.; GRATZER, P.F.; BEZUHLY, M.; HONG, P. Development and characterization of decellularized human nasosseptal cartilage matrix for use in tissue engineering. Laryngoscope, v.126, p.2226-2231, 2016.

HORN, M.M.; MARTINS, V.C.A.; GUZZI PLEPIS, A.M. Interaction of anionic collagen with chitosan: Effect on thermal and morphological characteristics. Carbohydr.Polymers, v.77, p.239-243, 2009.

LIU, M.; ZENG, X.; MA, C. et al. Injectable hydrogels for cartilage and boné tissue engineering. Bone Res., v.5, p.17014, 2017.

LIU, Z.Z.; WONG, M.L.; GRIFFITHS, L.G. Effect of bovine pericardial extracellular matrix scaffold niche on seeded human mesenchymal stem cell function. Sci. Rep. v.6, p.37089, 2016.

MECHAM, R.P. Methods in elastic tissue biology: elastin isolation and purification. Methods, v.45, p.32-41, 2008.

MESCHER, A.L. Junqueira's basic histology: text and atlas. 14.ed. New York: McGraw-Hill Education, 2015. 1136p.
MILLS, S.E. Histology for pathologists. 4.ed. Philadelphia, PA: Lippincott Williams e Wilkins, 2012. 1328p.

NAYYER, L.; PATEL, K.H.; ESMAEILI, A.; RIPPEL. et al. Tissue engineering: revolution and challenge in auricular cartilage reconstruction. Plast. Reconstr. Surg., v.129, p.1123-1137, 2012.

SILVA, J.M. GEORGI, N.; COSTA, R. et al. Nanostructured 3D constructs based on chitosan and chondroitin sulphate multilayers for cartilage tissue engineering. PloS One, v.8, p.e55451, 2013.

VEGA-RUIZ, B.; RAMOS-ZÚÑIGA, R.; DURAN, I.S.; URSIEL-ORTEGA, Y. Biomaterials and surgical applications: The translational perspective. Transl. Surg., v.2, p.85102, 2017.

WONG, M.L. WONG, J.L.; VAPNIARSKY, N.; GRIGGITHS, L.G. In vivo xenogeneic scaffold fate is determined by residual antigenicity and extracellular matrix preservation. Biomaterials, v.92, p.1-12, 2016.

WONG, M.L.; GRIGGITHS, L.G. Immunogenicity in xenogeneic scaffold generation: antigen removal vs. decellularization. Acta Biomater., v.10, p.1806-1816, 2014.

XU, K.; KUNTZ, L.A.; FOEHR, P. et al. Efficient decellularization for tissue engineering of the tendon-bone interface with preservation of biomechanics. PLoS One, v.12, p.e0171577, 2017.

ZAHMATI, A.H.A.; ALIPOOR, R.; SHAHMIRZADI, A.R. et al. Chemical decellularization methods and its effects on extracellular matrix. Intern. Med. Med. Invest. J., v.2, p.76-83, 2017. 